\title{
Images of Death in Agata Duda-Gracz's Variation on The Tempest
}

\begin{abstract}
The article presents an interpretation of Po Burzy Szekspira, Agata Duda-Gracz's adaptation of Shakespeare's The Tempest, as a play focused on the topic of death. The key feature of DudaGracz's theatre is authorial scenography, in which the visual metaphor is the main vehicle of meaning, not less important than the text. Her variation on Shakespeare's late drama is a story about unhappy life that results in frustration and desire for revenge, with death images being the most crucial elements of stage design, generated by amplifying the motifs of death found in The Tempest. Although Duda-Gracz concentrates mostly on individual suffering and personal failures, many stage design metaphors activate our collective traumas as well. Duda-Gracz's play is an interesting example of how today's theatre uses Shakespeare to deal with our fears, including the basic one - the fear of death.
\end{abstract}

Keywords: Shakespeare, Agata Duda-Gracz, The Tempest, Po Burzy Szekspira, stage design, images of death.

The Tempest is, as Simon Palfrey put it in his much acclaimed study Late Shakespeare. A New World of Words,

a work of anticipation, forever poised, like Ariel in the bough, upon the aching pulse of modernity. And in its magnetic island, Shakespeare offers the consummate incarnation of his "ur-" or anti-worlds, those wild places which magically precede, escape, judge, and sublimate the "split" communities of convention. [...] Simultaneously, the island is a place where memory - private and communal, mythical and imaginary, traumatic and tender can be replayed, repaired, or revenged. ${ }^{1}$

In Agata Duda-Gracz's latest Shakespearean scenario, Po Burzy Szekspira [After Shakespeare's Tempest], Prospero's island is visited and inspected as a space created both through and for the workings of memory. It is where the magician's memory preserves, via continual recollection of his miserably unsuccessful life,

\footnotetext{
1 S. Palfrey, Late Shakespeare. A New World of Words, Oxford 1999, p. 138.
} 
the most painful experiences and the deepest traumas. It is the prison for the one who remembers and, more significantly, for those remembered because by the power of his recollections they are forced to come back, again and again, and reenact their existences - as if they were alive - although their most desired dream is to be allowed to go, to be freed by fading into oblivion. My aim in this article is to argue that the key element in Duda-Gracz's interpretation of The Tempest is death and death-related themes. The director selects and amplifies the motifs of death found in Shakespeare's play and makes the variously constructed death images that constitute her scenography function as visual metaphors through which the viewers gain access to the meanings of her story.

Po Burzy Szekspira (Capitol Theatre, Wrocław 2016) is Duda-Gracz's fourth production inspired by Shakespeare. As in the previous ones - Romeo i Julia (Scena STU Theatre, Kraków 2008), Othello - wariacje na temat (Stefan Jaracz Theatre, Łódź 2009), and Każdy musi kiedyś umrzeć Porcelanko, based on Troilus and Cressida, (Słowackiego Theatre, Kraków 2013) - the director provides us with a highly eccentric reading of Shakespeare's classic, not so much to present a new interpretation, but in order to write her own story for which Shakespeare's text is a plane of reference. Critics describe Duda-Gracz's authorial theatre as marked by the artist's original imagination and characterised by a number of consistently employed methods, one of them being a creative approach to the adapted texts. The other key feature is structure based on rhythm and juxtaposition - her performances relay on refrains and other types of repetitions realized not only on the textual but also on the visual and musical levels. The characters she creates are weird, deformed, grotesque, or exaggerated, their costumes melted into scenography designed specifically for each particular project. ${ }^{2}$

As both director and stage designer Duda-Gracz creates very elaborate and vivid stage scenery for her productions, both when she works with other playwrights' texts and when she stages her own scripts. Asked in interviews about the importance of the visual appeal of her scenography and costumes, she emphasises that her theatrical imagination has been considerably influenced by her education as art historian. ${ }^{3}$ But there is a more direct reason why Duda-Gracz approaches the stage in a way very similar to a painter approaching a canvas. This is the legacy of her father, Jerzy Duda-Gracz, one of the most original Polish painters of the previous century, whose works are frequently "quoted" in the visual metaphors that lie at the core of her performances. While enriching her theatre by references to well-known paintings is a general feature of Duda-Gracz's stage design, in the case of Po Burzy... it is not only her father's art, but the father figure as such that remains in the centre of attention. Although the performance can be fully appreciated without any biographical key - fatherhood and father-daughter relationship belonging, after all, to the central topics of The Tempest - the director is quite open about the way in which Jerzy Duda-Gracz inspired her Prospero.

2 M. Mizera, Panoptikum à la Madame Duda-Gracz, "Teatr" 2009, nr 1, p. 27.

3 J. Kowalska, Smutek kapuścianych pól, "Teatr" 2016, nr 6, p. 15. 
The opening image presents an ageing man in a dirty T-shirt and striped pyjamas, sitting in front of the audience on a shabby sofa and staring at his reflection in the screen of a turned off TV. This situation is a theatrical reproduction of the last self-portrait of Jerzy Duda-Gracz, on which a frustrated forgotten artist contemplates his face and the dim reflection of his room visible on the dead television screen. Asked about the extent to which this production is actually about her father, the director recollects the painter's last years: "On the one hand [my father] had a sense that he was a failure - inferior, unfulfilled. On the other hand, he felt unappreciated. [...] In this bitterness and loneliness he resembled Prospero". ${ }^{4}$ Prospero's function in The Tempest is, as a critic once put it, "altogether peculiar. [...] He is the quintessence of a quintessence of a quintessence". ${ }^{5}$ Although DudaGracz's references to her relations with her father are very subtle, and much less foregrounded than the impact of his art on the theatre she creates, there is no doubt that he has always been the quintessential figure in her private and artistic life. In Po Burzy... she pays tribute to him, quarrels with him, and bids him good bye. But most importantly, through the character of Prospero, she studies the artist in him and in herself. While it is a commonplace to interpret The Tempest as the playwright's farewell to his art, even critics most "averse to reading Shakespeare as allegory [...] find it impossible to deny that Prospero is, to some extent, an imaginative paradigm of Shakespeare himself in his function as poet; and that he does in part embody Shakespeare's self-awareness at the conclusion of his poetic career". ${ }^{6}$ Duda-Gracz's production includes this interpretation, but is not limited to it. Its scope is broader and touches a number of topics - from ageing, disillusionment, loneliness, enmity, to home violence, self-destruction and, last but not least, death.

The multi-layered content of Po Burzy... hardly allows for a linear summary as it offers a kaleidoscopic view on a variety of situations from the characters' past. This relatively loose and overtly eclectic structure, with alternating day-time episodes and surreal dreams, may have been suggested by Shakespeare's text which also "works less as a straightforward narrative than a series of rich but profoundly enigmatic images". 7 In Duda-Gracz's play, instead of plot development there is a sequence of reiterated episodes in which the figures conjured back from the past by Propsero's tormented memory are forced to participate, unwilling as they are to do so. On the Capitol Theatre website the performance is described as a modern morality about the decline of humanity in a human being. Banal as it sounds, it aptly describes the director's intentions. Her characters are - or have become, or consider themselves to be - banal, common, mediocre, inferior. Duda-Gracz's Prospero may be a retired artist, but he is first and foremost an Everyman facing consequences of an unhappy life caused by wrong decisions, ignored chances and poisonous family relations that result in hatred and desire for revenge.

${ }^{4}$ J. Kowalska, Jestem irytująca. Z Agata Duda-Gracz rozmawia Jolanta Kowalska, "Teatr" 2016, nr 12, p. 16.

${ }_{5}^{5}$ J.M. Murry, Shakespeare, London 1948, p. 391-392.

${ }^{6}$ Ibid., p. 392.

7 The Oxford Companion to Shakespeare, eds. M. Dobson, S. Wells, Oxford 2001, p. 472. 
At the beginning of the play Prospero addresses the audience, welcoming them to imagine that they are granted a chance to methodically, secretly and without any fear of punishment revenge on everybody that has ever hurt them. And he takes the lead. Like Shakespeare's sorcerer, he possesses the magical "technology" to achieve his end but, unlike the rightful Duke of Milan, he knows precisely what he wants. As we are reminded by E.M.W. Tillyard in his classic study on Shakespeare's late plays, except for allowing Prospero to live and setting him adrift in a boat with his little daughter "the plot [of The Tempest] is entirely typical of Elizabethan revenge tragedy. Allow Prospero to be put to death, give him a son instead of a daughter to live and avenge him, and your tragic plot is complete". 9 Shakespeare's play is a romance variation on the popular genre. If it would be too optimistic to describe the play's ending as happy, there is at least some hope that the declared forgiveness of the old crimes opens a chance for peace and reconciliation. The Tempest's ending brings relief on many levels - the shipwrecks are relieved to be spared, Miranda and Ferdinand are relieved to be allowed to love, Ariel is relieved from his servitude, Prospero renounces his magic and asks the audience to mercifully relieve him from his role. Duda-Gracz undertakes the theme of revenge in a tragi-comical vein, but her Prospero is too bitter, too broken, and too hopeless to forgive.

His island is a living room in a block of flats typical of the Polish 1970s, with the wall unit, sofa and television set on a green carpet. This island is surrounded from three sides by the sea, that is by the viewers who are comfortably seated in the auditorium or less comfortably hidden behind the shelves of the wall unit to shamelessly watch what one of the reviewers aptly called a psychological strip show. ${ }^{10}$ The master of this island - unwashed, haggard, bored and arrogant - is the epitome of fall and failure. This is a Prospero with his staff already broken and his books discarded or forgotten. Once powerful and influential - an overwhelming husband and a tyrannical father - he has become reduced to a loser imagining that he can revenge on all the people he feels have wronged him in his frustrated life. His victims, the figures revived from the dead by his memories, are trapped in the cycle of recollections and fantasies. Their disorientation and desperation have roots in Shakespeare's shipwrecks:

The various groups $[\ldots]$ wandering the island, $[\ldots]$, deprived, almost driven to despair, threatened by madness, overwhelmed by wander and delight and tortured by impediments to their desires, little knowing that their plight is part of a master plan and that they are watched from above. [...] In the Tempest's island setting, through the unity of time, place and action, the atmosphere is almost claustrophobic. [...] We can zoom in and take the characters' own limited perspective, as in the initial storm and shipwreck, or out to Prospero's activities, where chance is resignified as design and destiny, or, interpreted negatively, as paranoid coherence. ${ }^{11}$

${ }^{8}$ V.M. Vaughan, A.T. Vaughan, Introduction [in:] W. Shakespeare, The Tempest, Walton-onThames Surrey 1999, p. 25.

9 E.M.W. Tillyard, Shakespeare's Last Plays, London 1968, p. 49.

${ }^{10}$ J. Kowalska, Smutek kapuścianych pól..., p. 57.

${ }^{11}$ I. Habermann, "I Shall Have Share in this Most Happy Wreck": Shakespeare's Topology of Shipwrecking, "Shakespeare Jahrbuch" 2012, vol. 148, p. 69, 70. 
These words of a critic commenting on the play's theatrical topology describe the aura of Duda-Gracz's Po Burzy... so precisely as if they have been written by a reviewer of her production. Claustrophobia - indeed, a suffocating density of the naked, ill or neglected bodies filling the stage - is very tangibly felt by the audience in the final episodes when all the protagonists get infected by Prospero's hopelessness and disappointment. Wearing, like him, dirty pyjamas and shabby T-shirts they remain seated in front of the dark screen of the broken television. This completely static scene takes long enough for the audience to become uncomfortable in their seats. After the actors have left the stage the viewers' uneasiness increases even more as they wait for them to break the theatrical illusion with their comeback for a round of applause. As Duda-Gracz's actors never come for the applause, this waiting can be very long. Discomfort and awkwardness that the audience is confronted with at the end effectively contrasts with Shakespearean release and relief. Prospero just stares in the audience until they become irritated, or bored, or afraid that this is never going to finish. They feel tainted by the reality show they have just witnessed, trapped in the obsessively reiterated acts of psychological and physical violence and scared by the vision of death that does not bring peace as "the storm in Duda-Gracz's performance is not an incident, but a repeatedly performed rite of self-torment". ${ }^{12}$

In his study of death-denying strategies dramatized in Shakespeare's plays James L. Calderwood - inspired by the cultural anthropologist, Ernest Becker argued that the means people employ to deal with and transcend the inevitability of death amount to life-long "immortality projects", which are both individual and cultural. "The denial of death is a fundamental motive not merely of individuals but of their cultures. [...] Humans [...] cannot live by survival alone. The selfawareness $[\ldots]$ makes us want not merely to be alive but to be meaningfully alive - to feel that what we do and are makes a difference". ${ }^{13}$ In The Tempest there are at least two such death-transcending projects undertaken in order to ensure symbolic immortality, and both are ultimately successful. One is social and communal - to regain the lost position of power, the dukedom of Milan, while the other is individual and personal - to save and protect one's child, as Shakespeare's Miranda is her father's "raison d'être, [...] his promise of immortality". ${ }^{14}$ In Po Burzy... Prospero's desire for revenge results from his failure to fulfil his immortality projects - be it his art, love or offspring. In Duda-Gracz's rewriting Miranda died as a baby, in a fire that consumed Prospero's house after his alcohol addicted wife had left a burning cigarette in her bed. Because the addiction had developed as a result of depression caused by an unhappy marriage, Miranda was a victim of her mother's negligence, but also, indirectly, also of her father. She - or rather her ghost imagined by Prospero as a girl on the verge of womanhood - is a perfect product of her father's education, able to give erudite speeches on all subjects possible, ranging from art to politics to feminism, and making a satisfying discussion partner for her father, an intellectual tyrant. In the nightmarish afterlife created by

\footnotetext{
12 J. Kowalska, Smutek kapuścianych pól..., p. 57.

13 J.L. Calderwood, Shakespeare and the Denial of Death, Amherst 1987, p. 4-5.

14 V.M. Vaughan, A.T. Vaughan, op. cit., p. 27.
} 
Prospero's memories this reincarnation of Miranda tries, ineffectively, to communicate with her mother, attempting to establish, albeit post mortem, a meaningful relationship. But Prospero's wife - always with a cigarette in her mouth, dressed in a pinkish bath-suit on crumpled pyjamas, her face red and swollen and her eyes full of unbearable suffering - is too distracted, self-centred, and emotionally wasted to develop, or revive, any bond with her lost child.

If there are hardly any links between Miranda and her mother, a character closely related to Miranda is Ariel, a kind of alter-ego of Prospero's daughter. They both died in the same fire accident in Prospero's house and they both obediently accompany Prospero in his memory-created inferno. Ariel is the most pointedly death-infected character in Duda-Gracz's version of The Tempest and this feature is visually foregrounded by her costume, make-up and properties. The thin, naked, ash-painted body and black eyes remind of her death in the flames. She likes to play with matches and stare at fire. She bears visible signs of mutilation - there are fresh, or never healing, wounds on her back where she used to have wings. Another mark of death are Ariel's mechanical, automatic movements - fulfilling her master's orders, she resembles a humanoid robot. She is not devoid of human emotions - compassion, but mostly fear - although they are buried very deeply under the trained aura of an unmoved, never surprised, servant. Last, but not least, Ariel's final freedom is death-marked. Instead of rejoicing in the end of her obligations, she gets crushed by the news that there has never been in her anything supernatural or magical. Ariel, convinced that she is Prospero's artistic tool, gets destroyed with disappointment when the master bluntly informs her that she is nothing more than an ugly naked body. Being thus reduced to the bodily, Ariel loses her immunity against death. According to the author of Shakespeare's Mortal Men, the playwright seeks

an art capable of confronting and mastering death, [one that] is kinetic and transformational. Since what is to be transformed is the death taint in our bodily-based existence, the transformation actions are versions of resurrection. [...] The Tempest repeatedly enacts resurrection. Human beings and destinies rise from the grave of the past [...] and the seemingly dead spring up from the oozy mud in which we are repeatedly told they lie buried. ${ }^{15}$

It is precisely this promise of transformational resurrection, the hope for a brighter future cleansed of the past crimes that Duda-Gracz converts into a hopeless cycle of never-ending suffering.

This is perhaps best seen in the character of Caliban, or rather the Calibans, as this protagonist is played by a pair of actors. He, an ageing hippie in colourful flower-power clothes, has an aura of a Gypsy fiddler. A kind of freebooter with no regular job he used to be employed in Prosepro's house to do small reparations. As the past mingles with the present and recollections merge with imagination, we see him repeatedly rape Miranda. His black wife, the she-Caliban, is an intimidated overworked woman, wearing a shabby housecoat and permanently carrying two shopping bags filled with vegetables and canned food. Before the

15 P.L. Carlin, Shakespeare's Mortal Men. Overcoming Death in History, Comedy and Tragedy, New York 1993, p. 124. 
fire she worked as a cleaning-lady in Prospero's house. Now, interested only in what to cook for her husband, she is eager to satisfy him and always hoping that one day he brings home the promised refrigerator so that she can stop storing food on the windowsill. Rummaging about her bags she resembles Beckettian characters trapped in aimless repetitions of everyday chores. This couple is introduced by Prospero as his poor neighbours and treated with utmost contempt, clearly underpinned by racist bias. There are no blatant allusions to the current social problems in Duda-Gracz's play, but in the time of an increasing migration crisis Prospero's question "Is there anything more vile than the so-called neighbours?" sounds disconcertingly topical. As the play progresses, the Calibans turn from the apparently innocent victimised neighbours into murderers. They decorate their heads with paper crowns and, dressed as the Macbeths, rebel against their malicious master. Prospero's suspicion against the poor neighbours constantly lurking though his windows turns out to have been well-grounded, but he cannot die in spite of repeated stabbing. This scene is "the most acute illustration of Porspero's existential prison". ${ }^{16}$ There is no escape. Not even in death.

The analysis of Duda-Gracz's repertoire of death images in Po Burzy... would not be complete without paying some attention to the storm and its casualties, the more so that in this version of The Tempest, the actual shipwreck is postponed to become the central episode. It is to be remembered that seafaring, navigation, maritime adventure and death on the sea were topics well familiar to Shakespeare's contemporaries. Their imagination would be fed by travel accounts, like the famous Principal Navigations, Voyages and Discoveries of the English Nation by Richard Hakluyt, arousing curiosity and thirst for adventure in individuals, and boosting national pride and colonial ambitions in the whole society. As "[t]ravel tales of voyages constituted one of the largest categories of popular reading of Shakespeare's period" 17 we know of three such texts that most probably lie behind The Tempest, all accounting on the much-discussed shipwreck of July 1609 caused by a storm at the coast of Bermuda. While this shipwreck and the, as it was believed, providential preservation of the survivals might have inspired the opening storm scene, Shakespeare coined a number of famous compounds that give us an idea of "the perils of early modern voyaging and of the rule of the goddess Fortune over seas wracked by storms and studded with hidden reefs"18 _ "stillvexed Bermudas", "sea-sorrow", "sea-change", "sea-swallowed". They are part of a large array of sea and seafaring metaphors that appear in his plays, only to mention Hamlet's "sea of troubles" as the most famous example.

Stephen Greenblatt called shipwreck one of Shakespeare's favourite manifestations of an unforeseen catastrophe, this vital structural element of his plots which "suddenly turns what had seemed like happy progress, prosperity, smooth sailing into disaster, terror, and loss". ${ }^{19}$ In The Tempest, as in his other late plays, the playwright adds another layer to his favourite motif, presenting it in a tragi-comical

${ }_{16}$ J. Kowalska, Smutek kapuścianych pól..., p. 58.

17 The Oxford Companion..., p. 482.

18 J. Bate, D. Thornton, Shakespeare Staging the World, London 2012, p. 238.

19 S. Greenblatt, Will in the World: How Shakespeare Became Shakespeare, New York 2004, p. 85. 
vein: a fake storm causes a fake shipwreck, "the happy shipwreck". ${ }^{20}$ Gonzalo's cry "we split" (1.1.62), heard in the opening scene, symbolises destruction by losing the security of status quo. "Conceived of as a secure, organic vessel, the unsplit ship can be a symbol of order [...]. The 'split' figures the breaking apart of the ship of state and $[\ldots]$ is a return to the confusion of the individual confronted with independence, with an existential and experiential loneliness". ${ }^{21}$ Prospero's shipwreck, caused and controlled by magic, was nothing else but a repetition of, and reaction to, the first one when he and Miranda were forced to depart from Milan on a wrecked and leaking ship. Instead of death they found independence and loneliness in becoming refugees on the island inhabited by Caliban, offspring of another exile.

So when Ferdinand and other shipwrecks land on the island they are put to the test of social isolation, in Duda-Gracz's story more difficult than in Shakespeare's because they are a group of strangers forced to be together by the situation that ensues the storm. When the convulsions of drowning are over the room fills with a group of weird figures: a music teacher, a stupid celebrity, a conceited journalist and a collective character called Everybody. Reared in Prospero's tormented mind, they are projections of the past traumas, phobias and resentments. On the island they are tormented by recurrent memories of their long and painful deaths, by disorientation and fear. Their inadvertent stay on the island of Prospero's memory reveals their worst features - egoism, self-righteousness, vanity, submissiveness, inability to love and sacrifice. In one of the best tragicomic scenes of the performance the shipwrecks are presented with a mock telephone exchange and Everybody is trying to call his wife and corporation colleagues to share with them "the news" about his extreme holidays on the tropical island. It is worth mentioning that creating a panopticon of human curiosities belongs to Agata Duda-Gracz's favourite techniques, frequently employed in her performances. Characterising the protagonists in Po Burzy... she draws inspirations from her father's paintings that use grotesque to depict passive, degraded, rejected men, monstrously big, neglected women, and all kinds of marginalized people, numbed by the pointlessness of living, suspended in a kind of death-in-life state. Such is Jerzy DudaGracz's "Hamlet Polny" [Field Hamlet], the other painting that is referred to in the character of Prospero. This Hamlet - his face and body ravaged by alcohol, his big belly hardly covered by a stretched T-shirt - is sitting on an old sofa in the middle of a cabbage field. Beside his legs in dirty striped pyjamas lies a skull. On his head he is wearing krakuska, a cap ornamented with ribbons and peacock feathers, characteristic of the Polish folk costume from the Kraków region. His eyes, hardly open, express dullness and fatigue.

It is this painting that the theatre critic Jolanta Kowalska had in mind when she titled her article on Po Burzy... Smutek kapuścianych pól [Sadness of the cabbage fields]. In her interpretation of Duda-Gracz's version of The Tempest she suggests that the only person capable of forgiveness is the creator of this performance.

${ }^{20}$ F. Kermode, Introduction, W. Shakespeare [in:] The Tempest, London-New York 1992, p. XXV.

${ }^{21}$ S. Palfrey, op. cit., 151. 
She is the real Prospero, her theatre is the island and Prospero's wand is held by the narrator whose voice introduces the subsequent episodes. The narrator's use of irony and pastiche have a soothing quality. ${ }^{22}$ In this context one word should be added about the play's ambiguous title. Po Burzy Szekspira may simply mean that Duda-Gracz's story was created with reference to, or as a reaction to, Shakespeare's play. It may also mean that - as after The Tempest there was no more playwrighting, no more poetry, no more artistic creation - her performance is about the death of an artist and the death of art. But one may also see a question hidden in the title. Not only what comes after The Tempest, but more acutely - and more universally - what comes after the tempest? In this case it is not a rainbow. It would be too much to expect any cathartic relief, although Duda-Gracz treats her characters - awful as they are - with pity and tenderness. Yet, she does not have for them any optimistic answer. Unlike Shakespeare's storm, her tempest is not a purifying experience. After the tempest there comes death.

In this variation on Shakespeare's last play, all characters are to some extent infected with death. The potential death of Prospero and his daughter is changed into their actual deaths: Prospero's daughter dies in an accident, he is killed by the Calibans, and if Alonso and Ferdinand are allowed to live, it is only in order to be inflicted with a punishment worse than drowning. Like all the other characters they, too, become Prosperos at the end. He makes them share his own death-in-life vegetation. Duda-Gracz's focus on the traumas of disintegrated life is visualised in vivid stage metaphors that, as I have tried to show above, work simultaneously on different micro-levels of the performance. Considered from a macro-perspective, two types of death images, contrastive in their nature, stand in the foreground - death in fire and death in water. On the one hand, there is Stefania's cigarette, Ariel's ashen body and frequent use of smoke, especially in group scenes, on the other - scenes of drowning after which the bodies of the casualties, and their luggage, lie scattered chaotically in the front stage, as if along the coast. And although it must be emphasised that Duda-Gracz's performance successfully escapes the traps of journalistic theatre, these images are bound to resonate more powerfully nowadays than they would have before the events that imprinted in our collective memory the haunting images of the burning WTC towers or the capsized refugee boats. Duda-Gracz's strongly visual theatre inscribes her Shakespearean scenario in an artistic context that enables us to enact, and helps us to understand, our individual and collective fears, including the most fundamental one, the fear of death.

22 J. Kowalska, Smutek kapuścianych pól..., p. 58. 


\section{Bibliography}

Bate J., Thornton D., Shakespeare Staging the World, London 2012.

Calderwood J.L., Shakespeare and the Denial of Death, Amherst 1987.

Carlin P.L., Shakespeare's Mortal Men. Overcoming Death in History, Comedy and Tragedy, New York 1993.

The Oxford Companion to Shakespeare, eds. M. Dobson, S. Wells, Oxford 2001.

Greenblatt S., Will in the World: How Shakespeare Became Shakespeare, New York 2004.

Habermann I., "I Shall Have Share in this Most Happy Wreck": Shakespeare's Topology of Shipwrecking, "Shakespeare Jahrbuch" 2012, vol. 148, p. 55-72.

Kermode F., Introduction, W. Shakespeare, The Tempest, London-New York 1992, p. xi-xciii.

Kowalska J., Smutek kapuścianych pól, “Teatr” 2016, nr 6, p. 56-58.

Kowalska J., Jestem irytujaca. Z Agata Duda-Gracz rozmawia Jolanta Kowalska, “Teatr" 2016, nr 12, p. 14-20.

Mizera M., Panoptikum à la Madame Duda-Gracz, “Teatr” 2009, nr 1, p. 26-29.

Murry J.M., Shakespeare, London 1948.

Palfrey S., Late Shakespeare. A New World of Words, Oxford 1999.

The Oxford Companion to Shakespeare, eds. M. Dobson, S. Wells, Oxford 2001.

Tillyard E.M.W., Shakespeare's Last Plays, London 1968.

Vaughan V.M., Vaughan A.T., Introduction [in:] W. Shakespeare, The Tempest, Walton-on-Thames Surrey 1999, p. 1-138. 